\title{
MEMÓRIAS DAS TRINCHEIRAS: OS ANIMAIS NA LITERATURA DA GRANDE GUERRA
}

Márcia Seabra Neves'

\begin{abstract}
RESUMO: Embora até recentemente o homem tenha detido o papel principal nos relatos sobre a Grande Guerra, a verdade é que os animais também foram atores diretos desse cenário bélico. No entanto, o contributo do soldado não-humano parece ter sido relegado para os bastidores deste teatro apocalíptico até às últimas décadas do século 20 , altura em que se assiste a uma verdadeira revolução do pensamento ocidental relativamente à condição animal e sua relação com o humano. Neste contexto, o crescente interesse teórico e crítico pela condição animal e a sua revalorização ético-científica lançaram um novo olhar - não especista, nem antropocêntrico - sobre a atuação militar destes heróis marginalizados e a sua relação com os seus companheiros humanos, com quem partilharam o inferno das trincheiras. Com efeito, os grandes discursos contemporâneos sobre a animalidade, centrados na renegociação da cartografia humano-animal a partir de um descentramento antropológico, propõem uma releitura simbólica da presença do animal da Grande Guerra, amplamente celebrada pelos soldados nos seus escritos memorialísticos, que compõem o abundante corpus de literatura testemunhal do pós-guerra.
\end{abstract}

Palavras-chave: Primeira Guerra mundial, humanos, animais, trincheiras, memórias.

\section{MEMOIRS FROM THE TRENCHES: ANIMALS IN GREAT WAR LITERATURE}

ABSTRACT: Even though man has up to recently assumed the role of protagonist in First World War narratives, it is undeniable that animals have also played a leading role in trench warfare. The key contribution of these non-human troops appears, nevertheless, to have been relegated to the backstage of the apocalyptic theatre of war up until the late $20^{\text {th }}$ century when a drastic revolution, concerning the western intellectual tradition on animal condition and its relationship with the human, was set in motion. In this respect, the growing philosophical interest in animal condition and the ensuing ethical and scientific reappraisal of animals have paved the way for a renewed perspective - no longer specist nor anthropocentric - on the military intervention of these marginalized heroes and on their relationship with the human soldiers with whom they experienced hell on earth in the trenches. By arguing for a renegotiation of the human-animal cartography from the alternative standpoint of anthropological decentering, pervasive contemporary discourses on animality have indeed allowed for a re-evaluation of the presence of animals in the Great War, repeatedly acknowledged and celebrated by soldiers in their memoirs, which make up a relevant section of the vast corpus of war testimonial literature.

Keywords: First World War, men, animals, trenches, memoirs.

A Primeira Guerra Mundial foi palco de mobilização e extermínio de centenas de milhares de animais. Estima-se que, ao longo dos quatro anos de conflito, tenham sido brutalmente arrastados para o teatro de guerra europeu cerca de 11 milhões de solípedes (muares e cavalos), 100000 cães, 200 a 250000 pombos-correios (BARATAY, 2013, p. 8-

\footnotetext{
${ }^{1}$ Márcia Seabra Neves, doutorada em Cultura pela Universidade de Aveiro (Portugal), é investigadora de pós-doutoramento no Instituto de Estudos de Literatura e Tradição da Universidade Nova de Lisboa, onde presentemente desenvolve um projeto de investigação subordinado ao tema "Zooficções: figuras da animalidade nas narrativas portuguesa e brasileira contemporâneas".
} 
9), entre muitos outros. Só de Portugal, terão partido para França, juntamente com o CEP - Corpo Expedicionário Português, 11721 solípedes, sem falar dos pombos-correios que integravam o corpo de engenharia e comunicações (AFONSO \& GOMES, 2010, p. 274).

Assim, por mais anacrónico e dissonante que possa parecer num conflito que se inscreveu na memória coletiva pela eficácia destrutiva da sua sofisticada tecnologia de guerra (metralhadoras, armas químicas, automóveis, aviões, tanques, etc.), a verdade é que os animais foram atores diretos desse cenário bélico. E se os ataques de cavalaria rapidamente foram substituídos pelo avanço dos tanques e da artilharia pesada, as imagens das longas colunas formadas simultaneamente por veículos motorizados e carroças puxadas por mulas e cavalos, ou das mensagens transportadas por cães e pombos quando o telégrafo ou o telefone deixavam de funcionar, perdurarão até ao final da guerra, que nunca dispensou a presença dos animais.

No entanto, se no rescaldo da hecatombe a magnitude da beligerância animal foi amplamente celebrada pelos soldados nos seus escritos memorialísticos, a verdade é que, a partir dos anos 30, o contributo do soldado não-humano parece ter sido esquecido ou relegado para os bastidores deste teatro apocalíptico. O homem deteve o papel principal até as últimas décadas do século 20 , altura em que se assiste a uma verdadeira revolução do pensamento ocidental relativamente à questão do animal e sua relação com o humano. Neste contexto, o crescente interesse teórico e crítico pela condição animal e a sua revalorização ético-científica, bem como a publicação de obras como War Horse, livro infanto-juvenil de Michael Morpurgo, publicado em 1982 e adaptado ao cinema por Steven Spielberg em 2011, lançaram um novo olhar sobre a atuação militar destes heróis marginalizados e a sua relação com os seus companheiros humanos, com quem partilharam o inferno das trincheiras.

\section{Bestiário de guerra}

Quando, em Agosto de 1914, deflagra a guerra na Europa Central, é lançada, nos países envolvidos, a ordem de mobilização geral, abrangendo tanto homens como animais. Durante o processo de requisição, os animais arrolados são incorporados num regimento, sendo-lhes atribuída matrícula e livrete militar, como se de verdadeiros soldados se tratasse. 
Cavalos, cães e pombos-correios serão os animais mais requisitados durante o conflito, prestando um precioso auxílio militar ao soldado.

Omnipresente ao longo de todo o conflito, o cavalo foi, sem dúvida, o animal com maior protagonismo bélico. Com efeito, em 1914, o cavalo de guerra mantinha-se presença indeclinável em qualquer estratégia ou operação militar e a cavalaria representava parte essencial de cada exército, constituindo também o seu principal elemento ofensivo. No entanto, a modernização da artilharia e do armamento pesado, bem como a estagnação da guerra nas trincheiras, tornaram os ataques de cavalaria obsoletos e muitos esquadrões de cavalaria, como por exemplo o do CEP, foram posteriormente dissolvidos e convertidos em companhias de infantaria ciclista.

A secção de cavalaria acabará por se extinguir, impulsionando uma reconversão do papel militar do cavalo, sem, contudo, precipitar o seu desaparecimento. $\mathrm{Na}$ realidade, o cavalo tornar-se-á cada vez mais indispensável ao longo do conflito, desempenhando as mais diversas e árduas funções. Apesar da progressão do automóvel e dos caminhos-deferro, o cavalo, e os equídeos em geral, mantêm-se o motor do exército. A capacidade que tinham em deslocarem-se por terrenos inacessíveis aos veículos motorizados favorecia o movimento das tropas e o abastecimento mais ágil das trincheiras.

Em Calvários da Flandres, o escritor e expedicionário português Augusto Casimiro descreve as longas colunas militares compostas por veículos e cavalos:

Pelas estradas desfilam os camiões e as viaturas militares. Lentos e enormes, possantes e pesados, os pesados cavalos da lavoura ferem com os seus grandes cascos o piso áspero das estradas, a terra planturosa e húmida dos campos. (CASIMIRO, 1920, p. 8-9)

A máquina completa, mas não substitui o animal. Segundo Éric Baratay, em 1918, em toda a frente Oeste, $80 \%$ dos regimentos de artilharia de campanha e 70\% dos de artilharia pesada ainda são hipomóveis (BARATAY, 2012, p. 37).

É, pois, nas missões de carga e transporte que a utilização dos equídeos é mais abundante e diversificada. Sozinhos ou atrelados a viaturas hipomóveis, os cavalos são, sobretudo, usados para transportar todo o tipo de mantimentos, armas e munições, artilharia pesada ou ainda feridos e cadáveres (humanos e não-humanos), estabelecendo a ligação entre as linhas mais recuadas e as da frente. 
Mais resistentes e também mais pequenos que os cavalos, os burros e as mulas marcarão presença cada vez mais assídua nas colunas de transporte e, sobretudo, nas trincheiras, onde se deslocam com maior facilidade e menor exposição à mira do inimigo, assegurando o aprovisionamento dos soldados.

A guerra revela-se terrível para os equídeos, usados e explorados até ao limite das suas forças. O calvário começa logo durante o transporte para a zona beligerante, sobretudo para os que vêm da América. Com efeito, a fim de suprir a necessidade crescente de cavalos e muares, os países aliados importam animais dos Estados Unidos e da Argentina, submetendo-os à longa e penosa travessia do Atlântico. Presos e amontoados uns nos outros, permanecendo hirtos e imóveis durante os 15 a 20 dias de viagem, nervosos e subnutridos, expostos às doenças contagiosas e privados de cuidados de saúde e higiene, muitos acabam por sucumbir antes de chegarem a terra. Para os que sobrevivem, a trágica epopéia agrava-se na zona de conflito, onde as condições de vida e de trabalho são ainda mais deploráveis.

A guerra de movimento (agosto-novembro de 1914) foi, sem dúvida, a mais mortífera para os cavalos, extenuados pelo cansaço dos longos e incessantes deslocamentos, pela fome e sede, pelo calor intenso, pelo mau estado das ferraduras e pelos ferimentos provocados pelo porte quase ininterrupto da sela ou do arnês. Transcrevemos as palavras acutilantes de um soldado francês sobre a morte da sua égua, que não resistiu ao cansaço no último dia da batalha do Marne:

Si le mot martyr pouvait consciemment s'appliquer aux bêtes, c'est celui qu'il faudrait employer. Nos montures nous ont donné toute leur résistance, jusqu'au dernier pas, jusqu'au dernier souffle. N'ayant pas, pour les soutenir, la force de la pensée, elles ont enduré passivement, sans jamais se plaindre, les blessures les plus hideuses, sur le dos en particulier, la fatigue causée par des étapes dépassant parfois cent kilomètres, la compression résultant du cavalier et de la selle, cette dernière restant jusqu'à quarante heures sur le dos meurtri, la faim, la soif quand les nécessités des combats empêchaient toute halte. (apud DEREX, 2014, p. 38).

Os animais que não conseguiam avançar eram deixados pelo caminho, abandonados a uma morte agonizante e solitária. Muitos deles não chegavam ao campo de batalha e aqueles que o atingiam caíam, quase todos, sob a rajada das primeiras metralhadoras. 
Com a estabilização da frente, em dezembro de 1914, homens e animais enterramse nas trincheiras e a chacina dos cavalos abranda. Com efeito, a guerra de posição torna-se menos mortífera do que a de movimento, mas nem por isso menos cruel. Nas trincheiras, tal como os homens e os outros animais, os cavalos foram vítimas das duas armas mais letíferas: os morteiros, que abriam crateras que "desenterravam os mortos e enterravam os vivos” (ROMA, 1921, p. 18), e os gases asfixiantes, responsáveis pela morte atroz e impiedosa dos soldados humanos e não-humanos. Quando não eram mortos pelo inimigo, os cavalos eram abatidos pelos seus próprios companheiros humanos para os libertarem da agonia causada pelos ferimentos de guerra, tal como testemunha o soldado alemão Erich Maria Remarque no seu romance célebre $A$ oeste nada de novo (1929),

\begin{abstract}
Nunca tinha ouvido cavalos a gritar e mal posso crer. É uma completa agonia. É a criatura martirizada, é uma dor selvagem e terrível a que geme assim. Tornamo-nos pálidos. O Detering levanta-se: "Em nome de Deus! Acabem-nos." (...) Os gritos dos animais tornam-se cada vez mais distintos. (...) propagam-se imensamente por toda a parte, entre o céu e a terra. (...) Percebemos um grupo escuro de enfermeiros com várias e grandes massas negras que se agitam. São os cavalos feridos. (...) Alguns continuam a galopar, caem e retomam a corrida. Um deles tem a barriga aberta, donde saem as tripas. Embaraça-se nelas e vai a terra, mas para se levantar ainda. (...) Sentamo-nos e tapamos as orelhas, mas, apesar disso, estas queixas, estes gritos de angústia, estes horríveis gemidos, penetramnos nos ouvidos, penetram tudo. (REMARQUE, 1971, p. 49-50)
\end{abstract}

Eram também abatidos os cavalos infetados com doenças como a sarna ou a doença de mormo (as mais frequentes), de modo a evitar a sua propagação. O serviço veterinário do exército francês contabilizou mais 60000 casos de cavalos com doença de mormo durante os quatro anos de guerra, alguns desses casos eram de origem natural ou endémica e outros de origem voluntária. Investigações recentes revelam que grande parte dessas epidemias terá sido provocada por uma guerra biológica ou bacteriológica secretamente levada a cabo pelos alemães contra os seus inimigos e que consistia em inocular doenças infeciosas nos equídeos e bovinos das tropas aliadas, com o objetivo de as fragilizar, minando a sua capacidade de ataque e resistência. No livro La France espione le monde, o jornalista e historiador francês Jean-Claude Delhez (2014, p. 309-313), partindo de mensagens alemãs da época, interceptadas e descodificadas pelos serviços secretos franceses, desvenda os meandros dessa guerra biológica mundial, da qual Portugal também terá sido vítima, como represália da sua entrada em guerra ao lado dos aliados. A 1 de fevereiro 
de 1917, o major Kalle, adido militar alemão em Madrid, transmite aos serviços secretos alemães a seguinte mensagem:

L'épidémie de morve au Portugal a pris une telle extension parmi les chevaux de troupe et les mulets que de nouveaux envois de troupes sont mis en question. On a dû débarquer, parait-il, 1800 animaux et 30 hommes, par suite de mort ou maladie. (apud DELHEZ, 2014, p. 313)

Em suma, mais de 1 milhão de cavalos morreu durante a guerra e aqueles que sobreviveram foram abatidos por velhice ou doença, vendidos a açougues ou simplesmente condenados ao esquecimento.

Outro ator principal desta trágica epopeia, embora com menos protagonismo e projeção do que o cavalo, foi o cão de guerra. Os cães tinham que ter entre 1 e 8 anos, entre 45 e 60 centímetros de ombros e, de preferência, o pêlo escuro. Depois de selecionados eram encaminhados para campos de treino cinotécnicos e submetidos a um rigoroso adestramento, sendo depois destacados para diferentes funções e missões de acordo com as suas qualidades (SAINT-BASTIEN, 2014, p. 47-48).

Os cães de busca, identificados com o símbolo da cruz vermelha no dorso, partiam para o campo de batalha em busca de soldados feridos, advertindo depois os maqueiros da sua presença e indicando-lhes a sua localização. Nesta missão de resgate e salvamento ${ }^{2}$, os cães eram também usados para transportar as macas com os feridos.

Se a eficácia dos cães de busca não foi reconhecida por todos os exércitos, como é o caso do francês, que suprimiu esse serviço em setembro de 1915, o mesmo não acontece com os cães de aprovisionamento, cada vez mais solicitados ao longo da guerra. Expostos ao fogo inimigo e equipados com selas especiais ou atrelados a pequenas viaturas com uma capacidade de carga de 15 a $18 \mathrm{~kg}$, os cães de aprovisionamento infiltravam-se

\footnotetext{
${ }^{2}$ Eis o testemunho de um soldado resgatado por um desses cães da cruz vermelha: "Atteint d'un éclat d'obus au bras, d'une balle dans la mâchoire et d'un coup de sabre qui m'avait décollé le cuir chevelu, j'étais à demi enfoui sous les cadavres de plusieurs camarades quand je sentis comme une caresse sur mon front: c'était un bon chien sanitaire qui me léchait la figure. Je parvins à me soulever un peu malgré mes vives souffrances. Je savais que des chiens sont dressés à rapporter au campement les képis des blessés mais le mien était perdu. Le brave chien hésitait. 'Va, lui dis-je, va mon toutou, va chercher les camarades!' Il me comprit, fila ventre à terre et, de retour au campement, se démena si bien, aboyant, tirant celui-ci, celui-là par la capote, qu'il attira l'attention de deux braves brancardiers. Il les mena jusqu'à moi ; j'étais sauvé ! ” (apud SAINT-BASTIEN, 2014, p. 67).
} 
discretamente nas trincheiras para abastecerem os soldados da primeira linha com comida e munições ${ }^{3}$.

Outros, os chamados cães mensageiros, transportavam mensagens e garantiam a ligação entre os soldados, substituindo o telefone e o telégrafo. Este serviço encontrava-se repartido entre os cães estafeta que asseguravam uma transmissão unilateral entre qualquer posto avançado e um ponto fixo de comando; e os cães de ligação que faziam trajetos de ida e volta entre dois pontos de contacto. Já os cães de patrulha ou de sentinela permaneciam na linha da frente. De faro e olfato particularmente apurado, eram capazes de detetar a presença do inimigo a longa distância e de reconhecer os diferentes ruídos de guerra. Estes cães ficavam concentrados e imóveis durante horas, vigiando o inimigo e alertando em caso de aproximação. O sucesso deste tipo de missão dependia diretamente da relação de cumplicidade e da eficácia de comunicação entre o cão e o seu parceiro humano. Era também nas trincheiras da frente que atuavam os cães detetores de gases que, graças ao seu faro, conseguiam sinalizar a chegada do perigo a tempo que os soldados colocassem as máscaras e se protegessem, a si próprios e aos animais (cães e cavalos), evitando assim muitas mortes por asfixia. Finalmente, na retaguarda, encontravam-se os cães de carga ou de transporte que, por serem mais pequenos e velozes do que os cavalos e atrelados a pequenas viaturas de tração canina, auxiliavam e substituíam os solípedes na carga de armamento, munições e víveres, sobretudo em zonas de neve.

Aos cavalos e cães de guerra, junta-se a columbofilia militar que, integrada no corpo de engenharia, e mais precisamente nos serviços telegráficos, desempenhou um papel fundamental durante a guerra. Com efeito, discreto, veloz e capaz de chegar ao seu destino nas condições mais adversas e de percorrer longas distâncias, o pombo-correio tornou-se o mais rápido e eficaz meio de comunicação em tempos de guerra, sendo cada vez mais requisitado pelos serviços de informação. Todos os países envolvidos na frente oeste os utilizaram intensivamente, nomeadamente o CEP, cujo serviço telegráfico passa a dispor de uma secção de pombais militares, logo a partir de fevereiro de 1917 (ANICETO, 2010, p. 290).

\footnotetext{
${ }^{3}$ Um soldado francês relata a derradeira e malograda missão de abastecimento da primeira linha do seu cão: "Il partait de son petit trot que vous connaissez, un peu ralenti par la charge du bât. Souvent, les boches tiraient sur lui, mais toujours ils le manquaient. Malheureusement, il a eu un accident stupide: en sautant au-dessus d'un faussé, il a dû retomber sur des morceaux de verre. Il ne pouvait plus se trainer sur ses pattes saignantes. Et les boches l'ont visé tranquillement comme une cible" (apud SAINT-BASTIEN, 2014, p. 61).
} 
Quando as linhas telefónicas eram destruídas, os cães mensageiros mortos e os sinais de luzes dissimulados pelo nevoeiro ou pelo pó e fumo dos bombardeamentos, só os pombos-correios conseguiam superar a falência das modernas tecnologias de comunicação, assumindo a transmissão de mensagens, ou columbogramas, entre as primeiras linhas do front, a artilharia e os postos de comando. O método consistia, de modo geral, em manter os pombos pouco nutridos, mal instalados e separados do sexo oposto, ou seja, numa situação de privação que os fizessem desejar voltar ao seu pombal, fixo ou móvel (DEREX, 2014, p. 84). Assim, na linha da frente, por exemplo, o soldado tirava o pombo do cesto onde o guardava, atava-lhe a mensagem à pata e soltava-o para que regressasse à base (SAINT-BASTIEN, 2014, p. 80).

Era também comum que, nos aviões, os pilotos fizessem a observação e o reconhecimento da área inimiga e transmitissem as informações recolhidas através dos pombos-correios, sem necessidade de aterrar. O mesmo acontecia a partir dos barcos e navios de guerra. No fundo, a columbofilia será uma prática militar comum a todas as forças armadas, sejam elas terrestres, aéreas ou navais.

Outra missão confiada aos pombos-correios era a de espionagem. Os franceses usavam-nos para comunicar com a zona ocupada pelos alemães, infiltrando-os nessa zona ao cuidado de agentes de confiança que depois os enviavam para França com informações cruciais. Quanto aos pombos alemães, consta-se que sobrevoavam a zona inimiga equipados com aparelhos fotográficos miniaturizados que permitiam a captura de imagens relativamente nítidas.

No entanto, cavalos, cães e pombos não foram os únicos bichos do bestiário da Grande Guerra. Se estes se revelaram um precioso auxílio militar para o soldado, outros houve que se impuseram como verdadeiros inimigos dos dois campos contendores. As trincheiras foram invadidas por pragas de ratos, ratazanas, moscas, piolhos, pulgas e outros parasitas. Os soldados do C.E.P. chamavam-lhes a faxina das trincheiras: "Ratos de todos os tamanhos e creio que de todas as raças e, no género parasitas, havia também uma grande e variada coleção" (ROMA, 1921, p. 14). Os ratos e os piolhos foram os piores inimigos dos beligerantes que não tiveram outra opção senão a da coabitação forçada.

Nas suas recordações da Grande Guerra, o soldado português, sapador ferroviário, Pedro Freitas descreve o campo de batalha como uma imensa e assustadora necrópole, 
onde "os cadáveres de soldados, mulas, cavalos e mais fragmentos macabros, são em abundância e em verdadeiro estado de putrefação" (FREITAS, 1935, p. 51).

Ora, os ratos são os primeiros beneficiários deste cenário horripilante de morte, putrefação e imundície, onde vorazmente se saciam com os cadáveres humanos e animais em decomposição. Erich Maria Remarque descreve-os do seguinte modo:

Os ratos são aqui particularmente repugnantes, por causa da sua grossura. São da espécie chamada "ratos de mortos". Têm abomináveis cabeças, maldosas e peladas, e sentimo-nos mal só de ver as suas caudas compridas e nuas. (REMARQUE, 1971, p. 76)

Da Terra de ninguém, infiltravam-se pelas trincheiras e abrigos, devorando tudo o que encontrassem e infernizando o quotidiano dos soldados. O Capitão Menezes Ferreira descreve, não sem alguma ironia, este êxodo de roedores para as trincheiras do CEP:

Os ratos, não pretendendo defender o Direito e a Liberdade dos Povos, nem exaltar a supremacia de um tirano ou de uma casta, aproveitavamse, como certos "neutrais", de tudo que de um ou outro lado os combatentes usam deixar nas trincheiras, e de tal modo o fazem que para mal de "João Ninguém", prevendo a penúria que já se desenha nos arraiais inimigos, desertam num verdadeiro êxodo para as três linhas defensivas do C.E.P. (FERREIRA, 1921, p. 46)

Para debelar esta praga, foram inúmeras as medidas intentadas. As mais eficazes terão sido as campanhas de desratização à base de tóxicos e o recurso a cães treinados para matar ratos e proteger as provisões (o cão surge, mais uma vez, como aliado indefectível do homem). Chegava mesmo a haver concursos da caça ao rato, em que o melhor caçador era premiado. Se o produto tóxico erradicava aproximadamente 370 ratos por dia, os cães também conseguiam aniquilar uma média de 80.

Outras medidas foram tomadas individualmente pelos soldados, como a invenção pelos franceses das camas-gaiola (lit-cage), cobertas por uma rede que resguardava o soldado dos ratos, proporcionando-lhe um sono mais descansado. No C.E.P. também não faltaram as estratégias de fuga às invasões noturnas do inimigo roedor, conforme relembra posteriormente o alferes João Pina de Morais:

Um rato enorme de dorso cilíndrico, côr de burel, passou esfomeado muitas vezes pelo abrigo. Procura de comer. Quando não há mais nada 
roem o pano engordorado de limpar as culatras ou o logar das nodos do fato. Se for preciso guardar um lunche que enodôe a algibeira, dorme-se uma hora. Uma ratazana comerá sem nos incomodar precisamente a parte do tecido engordorado. (MORAIS, 1919, p. 56)

No entanto, o humor e a poesia eram, sem dúvida, as armas que mais eficazmente amenizavam os efeitos da invasão dos roedores. $\mathrm{Na}$ impossibilidade de derrotá-los, os combatentes aprisionavam os ratos pela escrita, em poemas humorísticos, como o intitulado "Fado das balas e dos ratos", composto por Américo Mendes de Vasconcelos, "O Palhaes", de que reproduzimos o mote:

\author{
Por cima das nossas trincheiras \\ Passam as balas cantando; \\ Dentro dos nossos abrigos \\ Andam os ratos chiando. (RUSSO, 1924, p. 141)
}

É também com bonomia e resignação que os soldados encaram a luta diária contra outro inimigo parasitário tão ou mais devorador do que o rato: o piolho. A coabitação com estes pequenos e tenazes invasores é frequentemente evocada nos escritos de guerra, nomeadamente pelos soldados do CEP:

\footnotetext{
A Malta do grupo deita-se; e às tantas, a par do conchego estomacal, o camarada piolhinho também encontrando melhor pastagem, começa a fazer sentir a sua incómoda acção - e então, mesmo no embevecimento de alma em que nos encontramos, consoante é a ferroada do camaradinha das muitas pernas, assim é a nossa rápida intervenção no intuito apenas de o afugentar, porque... matá-lo? Isso já não merecia a pena... (Freitas, 1935, p. 88)
}

Com efeito, a falta de higiene individual e coletiva nas trincheiras, onde os combatentes não se lavavam, não se barbeavam, não se despiam, raramente se descalçavam e dormiam na palha, propiciava a proliferação dos piolhos, que resistiam a qualquer ataque humano. Desde desinfestações com inseticidas à desinfecção das roupas, passando pelos banhos obrigatórios, todas as medidas de combate se revelavam ineficazes. Catar o piolho tornou-se, pois, um ritual quotidiano obrigatório e um passatempo a que os soldados do CEP metaforicamente se referiam como a leitura do jornal, descrita por Pedro Freitas nos seguintes termos: 
'Ler o jornal' dizia-se de todo e qualquer soldado que todas as noites, sentado no seu beliche ou barraca, puxava pela camisa, ceroulas ou esfarrapados peúgos, e catando as várias camadas de cabelos do seu corpo se entretinha horas a matar o piolho que aos milhares o infestavam por todo o corpo e vestuário. Esse passatempo e acto de limpesa era sempre feito com certo alarido. (FREITAS, 1935, p. 279)

Tal como acontecia com os ratos, não conseguindo derrotar os piolhos, os soldados rendiam-se-lhes, através do humor e da ironia. Os franceses chamavam-lhes carinhosamente "les totos" e não dispensavam uma boa anedota, poema ou imagem humorística neles inspirada.

No CEP, o piolho era o protagonista de vários poemas e canções, como por exemplo "O piolho do soldado", um panegírico burlesco, em que se enaltecia a presença e atuação bélica deste companheiro cúmplice, descrevendo de modo jocoso a sua convivência com os soldados, ou melhor, nos soldados:

O piolho é um amigo

Que na paz ou no perigo

Acompanha o soldado

Ao morder, a gente sente

Que ele morde contente,

Para ser alimentado.

Lá no campo de batalha,

Entre a fúria da metralha

O piolho é um achado

Nas costuras da camisa

- Numa linha estabelecida

Do pescoço até ao rabo.

Quando há algum combate

Também assiste ao ataque,

Lá na sua posição,

$\mathrm{E}$, na luta corpo a corpo

O piolho vai ser morto

Ao golpe dum alemão.

Há piolho francês,

Há piolho inglês,

Há piolho alemão;

Há piolho italiano,

Há piolho americano,

- Eu tenho a convicção,

$[\ldots]$
O piolho assentou praça,

Povoou a sua raça

No corpo dos mobilizados;

E então êle hoje em França

Vai enchendo a sua pança

Com o sangue dos soldados.

O piolho lá na frente

Acompanha toda a gente,

Mostra a sua valentia.

Está sempre vigilante,

Mordendo sempre arrogante,

P'ra acordar a infantaria.

É deveras um guerreiro,

Um valente companheiro

Que não nos deixa ter sono;

Quando sente o alemão,

Ferra logo o seu ferrão,

E põe alerta o seu dono.

$[\ldots]$

No dia da ofensiva

Foi grande a sua fadiga

A morder, como se vê;

Mer'ceu bem uma medalha:

Lá no campo de batalha

Pôs alerta o C.E.P.

(RUSSO, 1924, p. 141) 
A este já vasto bestiário de guerra juntam-se ainda os animais usados para alimentar as tropas; os animais de quinta, perdidos por entre as linhas de combate; cães e gatos abandonados, vagueando pela terra de ninguém ou recolhidos pelos soldados; animais adotados como mascotes de regimento, entre muitos outros que, da linha da frente às zonas da retaguarda, partilharam com o soldado as agruras da guerra e os horrores de um apocalipse de que eram testemunhas involuntárias.

\section{Homens e animais: companheiros de trincheiras}

Pela sua especificidade tática, a $1^{\text {a }}$ Guerra Mundial obrigou a uma coabitação quase permanente entre o homem e o animal. Ora, a primeira consequência dessa proximidade e convívio entre os combatentes humanos e os não-humanos é, sem dúvida, a relação de companheirismo que, inevitavelmente, se estabelece entre ambos.

Aos animais militares e à faxina das trincheiras, juntam-se assim os animais de companhia e as chamadas mascotes. Os primeiros são, geralmente, animais perdidos e abandonados, sobretudo cães e gatos, que se refugiam nas trincheiras, criando laços de amizade com os soldados. Já as mascotes constituem a verdadeira arca de Noé das trincheiras (DEREX, 2014, p. 118), abarcando animais das mais variadas espécies, desde as mais comuns às mais exóticas (cães, cabras, javalis, macacos, ursos, leões, elefantes), adotados como símbolo ou imagem de marca de um regimento e cuja função consistia essencialmente em levantar o moral das tropas (SAINT-BASTIEN, 2014, p. 95-104).

Compartilhando com seus companheiros humanos o mesmo espaço de desconforto físico e horror psicológico, bem como o mesmo destino vital, os animais tornam-se cúmplices dos soldados, preenchendo assim o vazio afetivo que neles se fora acentuando com o afastamento, cada vez mais profundo, da vida civil.

São pois abundantes, nos testemunhos de guerra, as manifestações de afeto dos soldados para com os seus animais de companhia. Numa tocante carta, escrita das trincheiras ao seu filho, ainda pequeno, o capitão Augusto Casimiro do CEP descreve, com realismo pueril, a condição animal na zona de guerra e a sua relação com os soldados, que lhe proporcionam conforto e proteção em troca de uma presença portadora de esperança e 
consolo, instituindo-se entre ambos espaços de mútua cooperação, amizade e comunicação emocional.

\begin{abstract}
Antes da guerra, aqui, havia muitas casas, muitas Ribeiras, com jardins e árvores lindas, com avós, papás, mamãs, meninos, Assunções, Carlos malucos, coelhos, galinhas, cães, gatos e até os avôs destes ratos de hoje... Mas a guerra veio, vieram os alemães, os canhões, as balas... Tudo fugiu. As casas caíram no chão, as árvores ficaram estarrecidas, as galinhas e os coelhos deixaram-se comer... Só uma gata ficou... Da casa onde vivera apenas restava inteiro, a um canto, o lugar do fogão... (...) Nos dias dos combates, embravecida e miando, andou pelas árvores, pelas valas, escapou de todas as mortes... Depois vieram as trincheiras, os abrigos que pareciam casas e ela mudou para um deles, contente e ronronando, curvando a espinha preguiçosa, roçando-se pelas pernas de novos habitantes...

[...] Deixou-se ficar... Vivia de ratos e de saudades... Doente dos pulmões, com uma raleira que dá pena, (a pobre não usa máscara e apanhou gases...) - vive no meu abrigo, na Reserva, onde estou há dias... E há uns tempos que ela aparenta a barriga maiorzita... Chega-se à gente, mia devagarinho, come com apetite sardinhas de lata e tem uma tendência enorme para os cobertores do meu catre... Hoje de tarde meteu-se, aninhou-se ao meio do meu capote.

Eu escrevia essas linhas que aí vão... E num momento, ao terminar, quando fui vê-la, eram, no meu capote, uma gata e três gatinhos escorreitos... Nascidos às $17 \mathrm{~h}$ de hoje, no abrigo da Reserve Coy, Belfast Street, - linhas... Os gatinhos e a mãe passam bem. Estão na Maternidade, na toca do $1^{\circ}$ sargento... E um vai chamar-se Gurka, outro Balutchi e o terceiro conforme tu disseres e eu cumprirei... (CASIMIRO, 1918, p. 126-127).
\end{abstract}

Nesta busca incessante por uma humanidade em vias de extinção, até os animais normalmente considerados repugnantes se tornavam camaradas de infortúnio. Numa conferência proferida em maio de 1920, na Escola Militar, em propaganda da "Aldeia Portuguesa" na Flandres, o major Bento Esteves Roma, comandante de companhia no CEP, relata a sua relação de camaradagem com os ratos das trincheiras, verdadeira experiência de encontro com essa singular outridade animal:

Quando, após o a postos da manhã, me embrulhava na minha manta e nele deixava cair o corpo exausto de uma noite de constante alerta, era curioso o que se passava. Apagada a luz, começava a sentir um ruido afastado mas que se ia aproximando pouco a pouco. Em seguida, alguém vinha para junto de mim, de mansinho, com passos de pessoa amiga, não fosse eu concordar.

E, esse visitante não tardava a adquirir uma confiança sem limites, a ponto de se permitir passear por sobre mim, chegando a roçar pela minha cara a sua pele aveludada. Retirava-se e passado pouco tempo, 
comunicados os resultados da exploração, vinham mais, muitos mais e, então, já falavam, conversavam, fazendo uma chiada que só eles, os ratos, sabem fazer. (ROMA, 1921, p. 15)

Em L'animal que donc je suis, Jacques Derrida argumenta que o verdadeiro encontro com a outridade animal só é possível pela troca de olhares entre o homem e o animal, não o animal reconfigurado a partir de uma visão antropocêntrica, mas sim o animal real, aquele outro que existe em face de nós e que também nos olha (DERRIDA, 1999, p. 253-265).

Ora, é precisamente essa reciprocidade de um olhar interrogante que se surpreende entre este soldado e os seus companheiros, que embora conversassem e falassem como gente, nem por isso surgem privados de uma ontologia própria, chiando como só os da sua espécie sabem fazer.

Por outro lado, embora tenha começado com uma transgressão (por parte dos ratos) dos limites físicos entre ambos, a aproximação entre o soldado e os ratos só se efetivou com o movimento recíproco do olhar, ou seja, quando o soldado, sentindo-se observado pelos ratos - num curioso paralelo com a situação que, mais tarde, Derrida (1999, p. 253-265) evocará a propósito do seu gato - conseguiu verdadeiramente penetrar os seus olhos.

A princípio acendia a luz e eles iam-se embora, fugiam; mas dentro em pouco, apareciam lá no fundo, entre dois sacos de terra uns olhinhos muito brilhantes, a contemplarem-me com uma expressão de quem pede licença para continuar a festa interrompida. E, como o cansaço era muito, deixava-me adormecer. Acordava com a luz ainda acesa e, ao abrir os olhos, via os meus companheiros e amigos que se divertiam como se a luz estivesse apagada, fugindo somente quando me mexia. Dentro de poucos dias vivíamos em boa e franca camaradagem e eu nunca mais acendi a luz. (Roma, 1921, p. 15-16)

Em suma, soldados e animais irmanam-se num espaço comum de partilha de sentidos e afetos, assistindo-se a uma espécie de humanização do animal, que se transforma em amigo, companheiro, familiar, ou, por outras palavras, num outro substitutivo do ser humano, não perdendo contudo a sua ontologia animal.

É precisamente o que sustenta Éric Baratay, que se ocupa das relações entre o animal e o humano, no seu último livro intitulado Bêtes des tranchées: des vécus oubliés, no qual, a partir de dados históricos e etológicos, explora a presença e função dos animais na 
Grande Guerra, relegando o homem para segundo plano e concedendo protagonismo ao ponto de vista do animal.

O historiador francês defende que a ligação que se estabeleceu entre os soldados e os animais nas trincheiras não se baseia numa simples projeção antropológica do homem sobre o animal, mas antes num fenómeno de união recíproca entre dois sujeitos ativos (BARATAY, 2013, p. 111-112).

Baratay desconstrói, assim, os pressupostos especistas e antropocêntricos da tradição judaico-cristã e da filosofia ocidental que impuseram um corte radical e uma clivagem hierárquica entre o homem e o animal, afirmando que os animais não são meros objetos, nem tão pouco agentes passivos ou pólos secundários de uma relação de sentido único (homem - animal), mas antes "des acteurs agissants, réagissants, créant avec les hommes de véritables interactions et de vrais communautés avec leurs lots d'incompréhensions, d'ajustements, de violences, de résistances, d'échanges, d'empathies" (ibid., p. 11).

É, pois, necessário abandonar aquele antropomorfismo infantil, responsável pelo redutor binarismo que opõe a espécie humana e a espécie animal e relega os viventes nãohumanos para a base da pirâmide, ou o antropomorfismo de conclusão, que, ao contrário, projeta nos animais as qualidades humanas, conduzindo a uma indistinção das espécies (ibid., p. 16).

O especialista defende, sim, um antropomorfismo de questionamento que consiste em "se demander si telle faculté présente chez l'homme ne le serait pas, sous d'autres formes, en d'autres espèces" (ibid., p. 16). Por outras palavras, partindo do princípio de que o homem não é radicalmente diferente do animal, partilhando com ele insofismáveis semelhanças, Baratay aceita um antropomorfismo que equacione a possibilidade de uma dada faculdade humana poder também exisitir no animal.

No fundo, o que Baratay defende é uma relação animal com o animal. Para isso, o homem deve adentrar-se na pele do animal, de modo a incorporar a sua visão do mundo. Ora, durante as longas horas de espera nas trincheiras, o soldado teve muito tempo para observar os animais e, a partir dos seus comportamentos e atitudes, refletir acerca da sua própria essência. Nas palavras de Baratay,

La plupart du temps, ces animaux attirent le regard, mobilisent l'intérêt, occupent le temps des soldats, les font parler et beaucoup écrire (...). 
Car cette faune évoluant dans leur enfer quotidien incite les hommes à penser à la vie, à leur condition de soldat, à leur destin, à la mort. Ces méditations ne sont pas de simples projections sensibles sur des animaux prétextes, à peine regardés, écoutés, (...) mais le fruit de regards sur ces animaux, de prises en compte, de comparaisons et de croisements entre situations et attitudes des animaux et des hommes. (BARATAY, 2013, p. 129)

Em suma, a presença do animal na guerra vem revelar aos combatentes os limites da sua própria humanidade e o inominável absurdo do homem lobo do homem. Deste modo, o auxílio que os animais vêm trazer ao soldado não é apenas de ordem militar e tática, mas também ontológica, na medida em que o ajudam a conhecer-se a si próprio e a situar-se no mundo. Ora, num espaço e tempo em que a exploração de todas as dimensões do homem foram monstruosamente levada a extremos insuspeitados, o soldado acaba por ser desapossado da sua identidade humana, num processo de bestialização por vezes irreversível.

Com efeito, encarcerados em buracos enlameados, rastejando sobre restos de cadáveres profanados, confrontados com o espetáculo horrífico de vísceras expostas e gritos lancinantes de feridos que jaziam na terra de ninguém, os soldados da frente viviam como bichos, num cenário de rasura radical do humano. O major Bento Esteves Roma faz uma descrição vívida desse cenário macabro:

Apesar de haver cemitérios, muitos e muitos cadáveres havia enterrados pelas trincheiras. Um morteiro caindo e rebentando abria uma cratera, deixando a descoberto esses restos já putrefactos; ao mesmo tempo que escondia com a terra deslocada pela explosão os desgraçados que se encontravam junto do seu ponto de queda. Quantas vezes, como sucedeu com o meu batalhão, iam passando os dias sem nada a registar e, na própria madrugada da rendição, aparecia um morteiro que produzia às cinco e mais baixas. Depois, lá se andava procurando e recolhendo esses membros dispersos e ensanguentados, que ainda há pouco tinham vida. $\mathrm{E}$ mesmo assim, quantas vezes os corpos desses infelizes iam incompletos a enterrar! (ROMA, 1921, p. 18-19)

Nestes labirintos da morte, chamados trincheiras, o homem perde pouco a pouco a sua humanidade, regredindo ao grau zero da sua própria natureza. Nas palavras certeiras de Almada Negreiros, proferidas após uma visita aos campos de batalha do norte de França, "A trincheira é a reminiscência do troglodita" - "A humanidade foi ultrajada" (apud FREITAS, 1935, p. 52). 
Não são raros os testemunhos dos soldados em que, em voz própria, dão conta dessa sensação de viverem como bichos, neles se metamorfoseando, numa espécie de devir animalesco. Em $A$ oeste nada de novo, Erich Maria Remarque revela a barbárie que conduziu a esse ultraje da condição humana, degradando o homem numa carcaça despojada de humanidade:

\begin{abstract}
Tornamo-nos animais perigosos; não combatemos, defendemo-nos contra a destruição. (...) O furor que nos anima é insensato. Já não estamos agachados, impotentes sobre o cadafalso, mas antes podemos destruir e matar, para nos salvarmos (...). Dobrados como gatos, corremos inundados por esta vaga que nos arrasta, que nos torna cruéis, que faz de nós bandidos, assassinos e, se o quiserem, demónios - esta vaga que multiplica as nossas forças no meio da angústia, do furor e da ânsia de viver, que procura salvar-nos e que o consegue, mesmo. Se o teu pai se apresentasse ali como inimigo, tu não hesitarias em lhe arremessar uma granada em pleno peito. (Remarque, 1971, p. 85)
\end{abstract}

Assim, vivendo apenas o instante presente, guiado pelo medo e, sobretudo, pelo seu instinto animal de sobrevivência, o soldado acaba por adotar um comportamento bem mais animalesco do que o dos próprios animais. Do CEP, Quirino Monteiro e Melo Vieira testemunham essa dramática obliteração dos valores humanos:

\begin{abstract}
Não há tempo de pensar nem de acudir aos camaradas que tombam. A febre do combate torna os homens egoístas e indiferentes. Toda a sensibilidade se anula. Uma vida não vale nada; um corpo esfacelado é apenas um incidente; os gemidos não passam de sons que se juntam ao ruído infernal de tantos outros formado. Toda a trincheira está em fogo. (MONTEIRO \& VIEIRA, 1919, p. 37-38)
\end{abstract}

A bestialidade humana não se manifesta apenas no confronto entre soldados dos dois campos, mas também e, de forma ainda mais eloquente, em relação aos animais que, arrastados para uma guerra que nem sequer era a deles, foram muitas vezes vítimas das mais cruéis sevícias por parte do homem. Entre muitos outros episódios de violência gratuita do homem sobre o animal, Baratay evoca a sede de matar dos soldados que, nos angustiantes momentos de espera, atiravam conscientemente sobre qualquer animal que aparecesse na sua mira (2013, p. 119-120).

Saint-Bastien narra outro episódio revelador da bestialização do homem e da sua indiferença perante o sofrimento animal: o do cão armadilhado. Conta-se que os soldados alemães capturavam cães de resgate franceses e, por detrás do xairel da Cruz Vermelha, 
escondiam sacos cheios de granadas, libertando-os depois para que regressassem e explodissem nas suas trincheiras (SAINT-BASTIEN, 2014, p. 75).

$\mathrm{Na}$ realidade, a desterritorialização do humano para a esfera da animalidade é de tal modo radical que o soldado acaba por adquirir traços físicos denunciadores dessa metamorfose ou fusão com o não-humano, sendo, não raras vezes, designado através dessa analogia com o animal. É o caso do Corpo Expedicionário Português, ou CEP, metaforicamente apodado de "Carneiros de Exportação Portuguesa" ou "Cordeiros Portugueses exportados para abate", alcunhas a que não terão sido alheios os ridículos pelicos feitos em pele de carneiro que serviam de agasalho aos soldados do CEP (MARQUES, 2008, p. 150-151) ${ }^{4}$, mas também, e sobretudo, a impreparação militar das tropas portuguesas e a sua arriscada atuação na frente ocidental, tal como podemos deduzir pela palavras de João Chagas, no seu Diário:

É talvez um medico, talvez um sabio que também vae bater bater-se, e eu penso nas inclemencias, nas dores, nos horrores que vão conhecer estes seres d'élite, arrancados num dia às suas profissões espirituais, aos seus hábitos delicados, aos seus lares confortáveis e lançados como gado para dentro de wagons de $3^{\circ}$ classe que os despejará d'aqui a algumas horas no matadouro. (Chagas, 1929, p. 126-127)

Esta imagística disfórica das tropas como rebanhos ou manadas de gado enviados à força para o matadouro tornou-se comum em todos os exércitos e são abundantes as metáforas empregues para descrever essa condição animalizada do soldado. Fazendo uma compilação de várias metáforas animais do homem, recolhidas em diferentes autores, Erich Baratay traça, em palavras lapidares, o retrato físico e psicológico do soldado da Primeira Guerra:

Les hommes emmenés au front sont des troupeaux de moutons, des cochons engraissés, des veaux apeurés, de la viande fraîche remplaçant la

\footnotetext{
${ }^{4}$ O Tenente João Pina de Morais recorda com humor o impacto da samarra lusitana por terras de França: "De Portugal, mandaram o que nós chamávamos pelicos. Era uma çamarra talhada em forma de casaca sem mangas, e safões alentejanos, tudo feito em pele de carneiro e para proteger do frio. Era uma indumentária realmente um pouco ridícula, Os safões, esses são cómodos, mas a çamarra só serve para rir. [...] Os pelicos chegaram, distribuíram-se e lá foi um batalhão para as linhas vestido de carneiro. [...] Amigo alemão viu, apreciou, analizou - e quando começou a anoitecer, largaram a gritar da primeira linha deles: Mé! Mé! Depois imitando balidos e prolongando a onomatopeia: - Mé-é-é-é!” (MORAIS, 1919, p. 135).
} 
viande avariée des blessés et des morts, eux-mêmes bœufs écorchés, bêtes égorgées, animaux piégés, gibier traqué à l'instigation des hiérarchies, ces bouchers. (Baratay, 2013, p. 162).

Desde agentes de comunicação a informadores, passando pelas missões de transporte, reconhecimento, vigilância, socorrismo ou, simplesmente, de companheirismo e permuta afetiva, é inderrogável a omnipresença do animal em todas as frentes de combate. Oscilando paradoxalmente entre a agressão defensiva e o afeto empático, as relações entre o homem e o animal nas trincheiras assentam numa rede complexa de trocas e devires que se traduzem na diluição das suas fronteiras ontológicas e, em consequência, num fenómeno correlativo de humanização do animal e de bestialização do homem.

\section{Bibliografia teórica}

ANICETO, Afonso; GOMES, Carlos de Matos. Portugal e a Grande guerra. 1914-1918, Lisboa: Quid Novi, 2010.

BARATAY, Éric. Bêtes des tranchées: des vécus oublies. Paris: CNRS Éditions, 2013.

BARATAY, Éric. Le point de vue animal: une autre version de l'histoire. Paris: Éditions du Seuil, 2012.

DELHEZ, Jean-Claude. La France espione le monde (1914-1919). Paris: Ed. Economica, 2014. DEREX, Jean-Michel. Héros oubliés: les animaux dans la grande guerre. Paris: Éditions Pierre de Taillac et Ministère de la Défense, 2014.

MARQUES, Isabel Pestana. Das trincheiras, com saudade: a vida quotidiana dos militares portugueses na primeira guerra mundial. Lisboa: A Esfera dos Livros, 2008.

SAINT-BASTIEN, Jean-François, Les animaux dans la grande guerre, Tours, Éditions Sutton, 2014.

\section{Bibliografia memorialística}

CASIMIRO, Augusto. Nas trincheiras da Flandres. Porto: Edição da Renascença Portuguesa, 1918.

CASIMIRO, Augusto. Calvários da Flandres. Porto: Renascença Portuguesa, Rio de Janeiro: Luso-Brasiliana, 1920.

CHAGAS, João. Diário I - 1914. Lisboa: Livraria Editora, 1929. 
FERREIRA, Menezes. João Ninguém: soldado da grande guerra. Lisboa: Livraria Portugal-Brasil, 1921.

FREITAS, Pedro de. As minhas recordações da grande guerra. Lisboa: L.C.G.G., 1935.

MONTEIRO, Quirino; Vieira, Melo. Gambúsios - Soldados da Grande Guerra. Lisboa: Portugália Editora, 1919.

MORAIS, João Pina de. Ao parapeito. Porto: Edição da Renancença Portuguesa, 1919.

MORAIS, João Pina de. O soldado-saudade na grande guerra. Porto: Renascença Portuguesa, 1919.

REMARQUE, Erich Maria. A oeste nada de novo. Trad. Mário C. Pires. Lisboa: Publicações Europa-América, 1971.

ROMA, Bento Esteves. Os portugueses nas trincheiras da Grande Guerra. Lisboa: Cruzada das Mulheres Portuguesas, 1921. 